FILOZOFIA

Roč. 75,2020 , č. 8

DOI: https://doi.org/10.31577/filozofia.2020.75.8.6

\title{
MYSTERIÁNSTVÍ A DĚLBA EPISTEMICKÉ PRÁCE
}

FILIP TVRDÝ, Filozofická fakulta Univerzity Palackého v Olomouci, Katedra filozofie, Olomouc, ČR

TVRDÝ, F.: Mysterianism and the Division of Epistemic Labour

FILOZOFIA, 75, 2020, No 8, pp. $693-705$

\begin{abstract}
Mysterianism has become a popular stance in philosophy of consciousness and other philosophical subdisciplines. The aim of this paper is to show that mysterianism is not justified, mainly because its inclination to epistemic defeatism and the misunderstanding of the division of epistemic labour. In the first part, I will present the history of mysterianism in the $19^{\text {th }}$ and $20^{\text {th }}$ century philosophy. Then, in the second part, I will point out how epistemic defeatism is founded in the unwarranted philosophical futurology. The third part will deal with the division of labour in society, language and knowledge. Because of the division of epistemic labour, the understanding is distributed among numerous agents without possibility of individual comprehension. Finally, I will coin the term "ignorance illusion" that plays the central role in the mysterians' worldview.
\end{abstract}

Keywords: Epistemology - Philosophy of science - Mysterianism - Noam Chomsky Colin McGinn - Division of cognitive labour - Distributed understanding - Knowledge illusion

Pochybnost o lidských epistemických schopnostech patří k filozofii už od počátku jejích dějin. Představitelé filozofického skepticismu nedůvěřovali smyslům, znevažovali induktivní poznání, upozorňovali na nedostatky v logickém vyvozování, odhalovali omezenost introspekce. Někteří dospěli až ke globálnímu skepticismu a tvrdili, že veškeré poznání může být omylné. Další upadli do tenat nejhlubšího solipsismu, protože sám svět považovali za pouhé zdání a klam. Na konci 20. století se objevil nový způsob, jakým filozofové vyjadřovali svou skepsi ohledně lidské kognice. Pod hlavičkou mysteriánství začali hlásat, že řešení některých tradičních filozofických problémů bude navždy uzavřeno našemu chápání, protože existují pevně dané a nepřekročitelné hranice toho, co lidé dokážou pomocí filozofie a vědy vysvětlit. Autorem termínu mysteriánství je Owen J. Flanagan, jenž se inspiroval americkou garážovou kapelou z 60. let s enigmatickým názvem and the Mysterians (Flanagan 1991, 312 - 343). Podle Flanagana mysteriáni existovali a existují ve dvou variantách. „Staří mysteriáni“ byli dualisté, kteří mysl a vědomí vylučovali z přirozeného světa - mohli bychom proto hovořit o jakémsi ontologickém myste- 
riánství. Dnes jsou mnohem známější „,noví mysteriáni“, kteří jsou sice svým založením naturalisty, ale lidským poznávacím schopnostem upírají možnost pochopit vědomí a některé další jevy - jedná se tedy o mysteriánství epistemologické. Zatímco představitelé staršího mysteriánství připisovali vědomí nepřirozené či nadpřirozené vlastnosti a domnívali se, že se psychika řídí nepririrozenými či nadpřirozenými principy, zastánci novější varianty nevydělují vědomí z přirozeného světa. Flanagan je označuje za postmoderní skupinu, která využívá výstřední kličku, aby zarazila kůl do srdce scientismu $(1991,313)$. Mysteriáni totiž tvrdí, že věda nedisponuje potřebnými kompetencemi pro vysvětlení všech jevů, jež se v př́rodě nacházejí.

Flanagan považuje za zakladatele nového mysteriánství Thomase Nagela. Nejsem si jistý, zdali tak činí oprávněně. Mysteriánství tohoto typu má totiž v dějinách filozofie mnohem delší tradici a můžeme ho vystopovat až do druhé poloviny 19. století. Nagelovy názory navíc oscilují mezi nejrůznějšími pozicemi, a proto je obtížné provést nějaké jednoznačnější zařazení jeho stanoviska. Mysteriánství se liší od nauky o explanační propasti, která údajně odděluje subjektivně prožívané vědomí od objektivně založené vědy (např. Levine 1983). Naturalistické vysvětlení vědomí podle mysteriánů může existovat, ale lidské bytosti k němu nejsou schopny dospět. Zdá se mi, že Nagel zastává spíše antiredukcionismus a uvažuje o možnosti budoucí nereduktivní teorie vysvětlující vědomí. Má pro ni dokonce jméno „objektivní fenomenologie“, i když není zcela jasné, co tím vlastně myslí (Nagel 1974, 449). Některé jiné pasáže z Nagelových textů lze snad interpretovat jako mysteriánské, jako když v knize The View from Nowhere píše: „Představa úplného popisu reality, který by zároveň vysvětloval naši schopnost k realitě dospívat, je pouhým snem.. " ${ }^{1}$ At' je tomu s Nagelovým stanoviskem jakkoli, mysteriánství se stalo populárním nejen ve filozofii mysli, ale i v dalších fillozofických subdisciplínách. Cílem tohoto článku je prokázat, že se jedná o stanovisko neudržitelné, a to hned z několika důvodů. Mezi ty nejzávažnější patř́ inklinace $\mathrm{k}$ epistemickému defétismu a nepochopení epistemické dělby práce, na níž je založeno veškeré poznání vědy. V první části představím historii mysteriánství ve filozofii 19. a 20. století. Ve druhé se budu zabývat problematikou poraženectví ohledně vědeckého pokroku, které bývá ve filozofii spojeno s nezdůvodněnými futurologickými úvahami. Třetí část bude věnována dělbě práce ve společnosti, jazyce a poznání. Domnívám se, že právě distribuce epistemických kompetencí úspěšně vyvrací eventualitu kognitivní uzávěry. Nakonec zavedu pojem „iluze nevěděni“", který podle mě stojí v základech celé mysteriánské argumentace.

\footnotetext{
${ }^{1} \mathrm{~V}$ originále: „The idea of a full conception of reality that explains our ability to arrive at it is just a dream" (Nagel 1986, 85).
} 


\section{Dějiny mysteriánství}

Kořeny mysteriánského př́stupu ve filozofii mysli můžeme hledat u biologů a fyziků z druhé poloviny 19 . století. Úspěchy novověké vědy začaly u Newtona a vyvrcholily v Darwinově díle, ale osvícenecký étos optimismu nebyl sdílen všemi účastníky tohoto bezprecedentního rozmachu poznání. Své pochybnosti vyjádřil napríklad anglický biolog Thomas Huxley, který se stal hlavním propagátorem darwinismu a pro své mimořádné argumentační schopnosti byl nazýván „Darwinův buldok“. Huxley předpokládal, že evoluční teorie najde uplatnění snad ve všech oblastech vědy o živé př́rodě, ale ve svých textech přesto formuloval zásadní výjimku. Tou bylo lidské vědomí, které podle Huxleyho nelze v rámci biologie či neurologie uchopit:

Co je vědomí, nevíme. A jak se něco tak pozoruhodného jako stav vědomí přihodí v důsledku podráždění nervové tkáně, je stejně nevysvětlitelné jako zjevení džina, když Aladin třel svou lampu, nebo jako každý jiný základní fakt př́rody (Huxley 1866, 193). ${ }^{2}$

Ze závěrečné části Huxleyho citátu je patrné, že předpokládal nevysvětlitelnost nejen v případě mysli, ale i u dalších elementárních skutečností. Obdobně se k problému vědomí vyjádřil i Huxleyho starší současník, irský fyzik John Tyndall:

Přechod od fyziky mozku ke korespondujícím faktům vědomí si nelze představit jako výsledek mechanických procesů. Připustíme-li, že konkrétní myšlenka a konkrétní molekulární aktivita v mozku se přihodí ve stejném okamžiku, pak nedisponujeme duševním orgánem a patrně ani rudimentem takového orgánu, který by nám umožnil úspěšně uchopit přechod od jednoho jevu k druhému. Oba jevy se odehrávají současně, a my nevíme proč. Pokud by se naše mysli a smysly rozvinuly, zesílily a zbystřily tak, abychom dokázali vidět a pocitovat samotné molekuly mozku, pokud bychom byli schopni sledovat všechny jejich pohyby, uskupení a př́ípadné elektrické výboje, a pokud bychom byli zároveň důvěrně seznámeni s korespondujícími stavy myšlení a cítění, byli bychom pořád stejně vzdáleni řešení problému „Jak jsou tyto fyzikální procesy spojeny s fakty vědomí?“" Průrva mezi těmito dvěma tř́́dami jevů by nadále zůstala rozumově nepřekonatelná (Tyndall 1879, 86 - 87).

${ }^{2} \mathrm{~V}$ pozdějších vydáních je zmínka o džinovi a Aladinově lampě vypuštěna (např. Huxley 1872 , 188). 
Ještě hlubší rezervovanost $\mathrm{k}$ možnostem vědy projevil německý lékař Emil du Bois-Reymond:

Dokážu, a to podle mého názoru přesvědčivě, že vědomí nelze vysvětlit materiálními podmínkami nejen v současném stavu vědy, což každý ochotně uzná, ale že z povahy věcí nemůže být těmito podmínkami vysvětleno nikdy. Opačný názor, že se nesmíme vzdát naděje na vysvětlení vědomí materiálními podmínkami a že za stovky či tisíce let může lidská mysl proniknout do dřive nemyslitelných oblastí poznání, a proto uspět i tam, kde nyní selháváme - to je omyl, se kterým zde chci bojovat (du Bois-Reymond 1874, 24).

Du Bois-Reymond se domníval, že filozofie a věda se nikdy nedokážou vypořádat se „sedmi transcendentálními obtížemi“, které zasahují do všech částí lidského poznání: 1) existence hmoty a síly, 2) počátek pohybu, 3) původ života, 4) teleologické uspořádání přírody, 5) původ jednoduchých počitků, 6) vznik inteligentního myšlení a jazyka, 7) původ svobodné vůle (du Bois-Reymond 1882). Jak ještě uvidíme v následujícím výkladu, přinejmenším poslední dvě otázky jsou považovány za nezodpověditelné i dnešními mysteriány, přičemž ti nejvíce skeptičtí by pravděpodobně přijali jako neřešitelný celý seznam.

Rozmach současného mysteriánství umožnil svými texty ze 70. a následujících let americký filozof jazyka Noam Chomsky. Podle Chomského je při studia jazyka i mysli třeba odlišovat mezi dvěma typy otázek, které si badatelé kladou. První typ označuje Chomsky jako problémy - jsou v dosahu našich teorií, jejich pojmový aparát je pro nás pochopitelný, aspoň přiměřeným způsobem jim rozumíme. Druhým typem jsou ovšem záhady (mysteries), které jsou pro nás stejně netransparentní jako tehdy, kdy byly poprvé formulovány. U problémů existuje reálná šance, že je někdy dokážeme rozlousknout, zatímco $\mathrm{v}$ př́ípadě záhad jsme odsouzeni $\mathrm{k}$ věčné neznalosti (Chomsky 1975, 137; 1976, 281; srov. 2000, 83). Nejen, že jejich řešení neznáme, ale ani si nedokážeme představit, jak by aspoň přibližně mělo vypadat. Lingvistickým př́kladem problému je průběh osvojování jazyka, $\mathrm{k}$ jehož řešení Chomsky přispěl svou teorií o nedostatečnosti vnějších podnětů při dětském učení. Naopak, skutečnou záhadou je kreativní aspekt používání jazyka. Podle Chomského jsou naše kognitivní schopnosti natolik limitované, že nikdy nepochopíme, jak z konečného a relativně malého repertoáru gramatických prostředků dokážeme produkovat potenciálně nekonečné množství smysluplných výpovědí. Chomsky se domnívá, že demarkace mezi problémy a záhadami je podmíněna biologicky - kognitivní výbava umožňuje různým živočišným druhům nahližžet a řešit různé problémy. Chomsky tuto skutečnost často ilustruje svým oblíbeným př́kladem. Potkani se nedokážou zabývat komplikovanějšími matematickými úlohami, jako jsou např. bludiště založená na prvočíslech, 
protože jim k tomu chybí potřebný pojmový aparát. Znamená to, že potkani nemohou uspokojivě zodpovědět určitý typ otázek, protože si je kvưli svým konceptuálním limitům nemohou ani položit. Chomsky pak předpokládá, že podobná kognitivní omezení existují i u člověka (Chomsky 1988, 147 - 150; 1991, 41; 1993, 44 - 45; 1994, $188 ; 1995,2 ; 2000,107 ; 2009,185)$. Nechci se zatím zabývat nějakou systematičtější kritikou Chomského pozice, dovolím si zde jen krátkou poznámku, proč jeho př́klad s potkany neobstojí. Analogie není prriléhavá, protože na rozdíl od potkanů si my lidé můžeme položit otázky po povaze vědomí a původu jazyka. Disponujeme potřebnými konceptuálními prostředky pro jejich formulaci, jinak by ani nemohly vzniknout Chomského pesimistické úvahy.

Distinkce mezi problémy a záhadami padla ve filozofii mysli na úrodnou půdu, v 80. letech ji přijali a rozvinuli Jerry Fodor a Colin McGinn. Fodor považoval epistemickou omezenost (epistemic boundedness) za důsledek své modulární teorie mysli. Mysl je podle něj rozdělena do samostatně operujících komputačních mechanismů se zvláštním účelem - do modulů. $Z$ takto chápané kognitivní architektury podle Fodora nutně vyplývá, že počet modulů je omezen. Zajisté existují účely, kterým není věnován žádný modul, a proto se jimi mysli nemohou zaobírat. Epistemická omezenost pak spočívá v tvrzení, že i ty nejlepší vědecké teorie popisující strukturu světa budou obsahovat bílá místa, protože pro vysvětlení určitých záležitostí lidem chybí kognitivní prostředky. Tato mentální omezení mají závažné epistemické důsledky - některá přesvědčení nedokážeme vůbec formulovat, určitým problémům nebudeme nikdy rozumět (Fodor 1983, 120). Obdobný argumentační postup najdeme i u McGinna, který preferuje termín kognitivní uzávěra (cognitive closure). V otázce vysvětlení vědomí není McGinn dualista ani antiredukcionista, své stanovisko idiosynkraticky označuje jako „transcendentální naturalismus“. Fungování mysli podle něj je a bude neřešitelnou záhadou, protože se z definice vzpírá jakýmkoli pokusům o uchopení (McGinn 1989; 1991). McGinnův argument je založen na dvou premisách: 1) introspekce nás informuje o fenomenálních, ale nikoli neurálních stavech;2) percepce nás - prostřednictvím snímkování mozku - informuje o neurálních, ale nikoli fenomenálních stavech. Podle McGinna neexistuje žádný myslitelný způsob, jak tento rozpor překonat, a proto je jakýkoli pokus o všezahrnující teorii mysli odsouzen k neúspěchu. Samotnou kognitivní uzávěru lze pak definovat následovně:

Mysl typu $M$ je kognitivně uzavřená vzhledem k nějaké vlastnosti $P$ (nebo teorii $T$ ) tehdy a jen tehdy, nelze-li pojmotvorné procedury, které má $M \mathrm{k}$ dispozici, rozšírit tak, aby $M$ mohla pochopit $P$ (nebo $T$ ) (McGinn 1989, 350; český překlad podle Hř́bek 2017, 301). 
McGinn považuje za zjevné, že různé druhy myslí jsou vybaveny rozdílnými schopnostmi a zatíženy odlišnými omezeními, zkresleními a slepými skvrnami. To, co dokáže jedna mysl, jiná nesvede. McGinnovo explicitně formulované mysteriánství se stalo terčem dosti nevybíravé kritiky. Daniel Dennett reagoval na McGinnovu knihu (1991) uštěpačnou recenzí, v níž pozici označil za „neuvěřitelnou a směšnou“ a dodal, že v něm jako kolegovi vzbuzuje pocit trapnosti (Dennett 1991, 10). Pozastavil se nad tím, že McGinn nadužívá obrat „zdá se“ a že tak činí na úkor pečlivější argumentace. Odsudky Dennetta a Flanagana ovšem nezabránily tomu, aby se z mysteriánství stala teorie populární i za hranicemi diskusí o vědomí. Sám McGinn později mezi záhady zařadil vlastně vše, čím se filozofové zabývají: vědomí, já, význam, svobodnou vůli, a priori, empirické poznání (McGinn 1993). Pokud by to tak skutečně bylo, pak by filozofie neměla za úkol zkoumat nic jiného než pouhé hranice už tak dosti umenšeného lidského poznání.

Epistemická omezenost a kognitivní uzavřenost začaly být oblíbenými argumentačními strategiemi filozofü, kteří odmítají naturalismus. Např́klad Peter van Inwagen prohlásil, že je mu mysteriánství Chomského a McGinna blízké, protože dobře vystihuje záhadu svobodné vůle. Současný stav poznání nám totiž přesvědčivě ukazuje, že svobodná vůle není možná, přestože my jako lidské bytosti s jistotou víme, že existuje. Van Inwagen přiznal, že tuto záhadu nesvedl vyřešit on sám, a zároveň vyjádřil pochybnosti, že by to dokázal kdokoli jiný (van Inwagen 1998, 374; 2000). Prvky mysteriánství lze vypozorovat i u jiných s naturalismem sympatizujících myslitelů (srov. Pinker 1997, 561 - 565; Penrose 2004, 17 - 21; Horgan 2015). V dalších oddílech se pokusím ukázat, proč je tento př́ístup nezdůvodněný.

\section{Epistemický defétismus}

Skepticismus hlásající opatrnost při vynášení soudů a obezřetnost k vlastním poznávacím schopnostem je zajisté chvályhodným filozofickým východiskem. Neměl by ale přerůstat $\mathrm{v}$ epistemický defétismus, který poraženecky proklamuje marnost jakéhokoli snažení v oblasti poznání. Je samozrejmě možné, že lidskou mysl limitují kognitivní a epistemická omezení. Právě kvůli nim si ale nemůžeme být jistí, kde přesně se nacházejí. Tvrzení o epistemické omezenosti či kognitivní uzavřenosti není známkou skromnosti při formulaci vlastních filozofických závěrů, ale naopak př́ilišné sebejistoty ohledně neudržitelnosti názorů odlišných. Této skutečnosti si povšiml už Charles Darwin, když v knize $O$ původu člověka napsal: 
Nevědomost je mnohem častější př́ícinou sebedůvěry než poznání. Jsou to ti, kteří vědí málo, nikoli ti, kteří vědí mnoho, kdo s jistotou tvrdí, že ten či onen problém věda nikdy nevyřeší (Darwin 1871,3 ). ${ }^{3}$

Filozofové $\mathrm{k}$ argumentům $\mathrm{z}$ neznalosti sahají až př́liš často, jejich bezútěšné předpovědi mají někdy blíže $\mathrm{k}$ futurologii než serióznímu bádání. ${ }^{4}$ Takové chyby se dopustil i Immanuel Kant, když v roce 1790 konstatoval principiální nemožnost ryze materialistického vysvětlení živé př́rody:

Je totiž úplně jisté, že organické bytosti a jejich vnitřní možnost nemůžeme podle pouhých mechanických principů prírody ani dostatečně poznat, tím méně si je vysvětlit; a je to tak jisté, že lze směle říci, že je pro lidi nesmyslné o tom jen přemýšlet nebo doufat, že by se snad jednou zase mohl objevit nějaký Newton, který by dokázal učinit pochopitelným dokonce i vznikání stébla trávy podle prírodních zákonů, které by neuspořádal žádný úmysl. Naopak, takovou prozíravost je nutno lidem naprosto upř́ít (Kant 1975, 191 - 192).

Mnozí biologové se domnívají, že tímto „Newtonem stébla trávy“ byl právě Darwin se svou teorií evoluce založené na mechanismu přirozeného a pohlavního výběru, která byla poprvé publikována roku 1859. Jiným filozofem neoprávněně hádajícím budoucí vývoj vědy byl Auguste Comte, podle něhož bude naše poznání dalekých vesmírných těles vždy zatíženo neúplností. Comte v Kurzu pozitivní filozofie z roku 1835 autoritativně tvrdil, že můžeme mít znalosti o jejich geometrických a mechanických vlastnostech - vzdálenosti, velikosti a pohybu -, ale nikdy nebudeme vědět nic o jejich chemických nebo mineralogických kvalitách (Comte 1853, 137 - 138). Tentokrát trvalo pouhé čtvrtstoletí, než Gustav Kirchhoff a Robert Bunsen popsali objev spektrometru, a položili tak základy stelární a planetární spektroskopie, odhalující mimo jiné i chemické složení hvězd a exoplanet (Kirchhoff a Bunsen 1860; srov. Hearnshaw 2010).

Mysteriánské teorie Chomského, McGinna a dalších opakují argumenty svých předchůdců z 19. století. McGinn se domnívá, že přes veškeré snahy filozofů a vědců vyřešit psychofyzický problém záhada vědomí přetrvá. Vyzývá badatele, aby konečně přiznali porážku a vzdali se budoucího výzkumu, protože lidská kognice nebude nikdy

\footnotetext{
${ }^{3}$ Překlad jsem upravil, protože české vydání zcela neodpovídá originálu (srov. Darwin 2006, 19). ${ }^{4}$ Podobnosti mezi mysteriánstvím a futurologií si při kritice Chomského povšiml i filozof jazyka John Collins: „This is not to say that there are no mysteries, and only problems; the appropriate conclusion is that the distinction between the two cannot be empirically grounded; rather than being an issue in cognitive science, the question is a piece of futurology, interesting enough to speculate on, but not something to be greatly exercised about" (Collins 2002, 131). Já sám jsem obdobný argument rozvinul v Tvrdý $(2014,155$ - 156, 181; 2015, $104-108)$.
} 
uzpůsobena k pochopení těch nejhlubších tajemství vesmíru (McGinn 1989, 349, 361 - 362). Filozofická představivost je ale př́liš malá na to, aby dokázala uspokojivě predikovat budoucí objevy a vynálezy - minulost nás o tom přesvědčuje dnes a denně. Kantova neschopnost předpovědět překotný vývoj evoluční biologie a Comtovo nepochopení principů moderní astrofyziky až př́liš připomínají ohlašování hranic vědy u mysteriánsky laděných myslitelů. Žádoucím stanoviskem je ve vědě opatrný optimismus bez nadbytečných spekulací. Filozofičtí mysteriáni promrhávají svůj intelektuální potenciál, aby ukázali, proč něco nelze vyřešit, místo aby se sami pokusili aktivně přispět k řešení. Epistemický defétismus je popřením koncepce otevřené vědy, v níž samostatně pracující týmy výzkumníků přispívají ke kumulaci poznání. Základní chyba mysteriánů tak spočívá v nepochopení dělby epistemické práce, čímž se budu zabývat $v$ následujícím oddíle.

\section{Dělba epistemické práce}

Dělba práce je v centru zájmu filozofů hned na několika úrovních. Podle dlouhé tradice od Platóna po Marxe a dál se jednotlivci ve společnosti specializují na konkrétní výdělečné činnosti, což vede $\mathrm{k}$ vyšší produktivitě práce, lepší kvalitě produktů a nižším výrobním nákladům. Nejznámějším filozofickým dokladem společenské dělby práce je argument Adama Smithe týkající se výroby špendlíků. Smith ukázal, že specializace při jednotlivých výrobních úkonech těží ze zvyšující se zručnosti dělníků, která vede $\mathrm{k}$ úspoře času. Pracovníci jsou tak navíc motivováni $\mathrm{k}$ vymýšlení nejrůznějších zlepšováků, př́strojů a strojů, jež jim práci usnadňují (Smith 2016, 7 - 12). Už před Smithem ale podobným způsobem dělbu práce popisoval jeho př́tel David Hume, podle něhož distribuce pracovních aktivit zvyšuje životní úroveň a zajišt'uje stabilitu společnosti (Hume 2007, T 3.2.2.3, 312).

Myšlenka dělby práce byla později přenesena do jiných kontextů. Asi nejznámější je hypotéza o lingvistické dělbě práce, kterou do filozofie jazyka zavedl Hilary Putnam (1973) a jež se stala základem sémantického externalismu. Podle Putnama ne každý mluvčí zná referenci pojmů, které použivá, a proto se laici musejí spoléhat na znalosti expertů ve svém jazykovém společenství. U některých základních pojmů není lingvistická dělba téměř třeba (např. „židle“), méně triviální př́íklady ale distribuci jazykových kompetencí předpokládají, či dokonce vyžadují (např. „zlato“). Putnam se domnívá, že ve světě existují dva druhy nástrojů. Některé - jako kladivo nebo šroubovák - mohou používat jednotlivci, ale jiné - jako parní lodě - mohou být ovládány jen za součinnosti mnoha lidí. Slova jsou nástrojem druhého typu, protože jejich individuální použití nemá větší šanci na úspěch (Putnam 1973, 706). Lidé musejí v jazyce kooperovat, rozdělit si znalosti, specializovat se v určitých oborech. Radikálnější variantu tohoto př́stupu představili proponenti aktivního externalismu a rozšiřrené mysli, 
Andy Clark a David Chalmers. Ti tvrdí, že mezi naše kognitivní nástroje nepatř́i jen vnitřní obsahy myslí, ale i vnější objekty jako plnicí pera, listy papíru, poznámkové bloky, logaritmická pravítka, prsty na počítání - ale také artefakty sociálně rozšířené kognice jako knihy, diagramy, mentální stavy jiných osob, dokonce sám jazyk či celek kulturních prredstav (Clark, Chalmers 1998, 8).

Od společenské a lingvistické dělby práce je jen krůček k dělbě vědecké. Je zjevné, že některé matematické a vědecké otázky bychom nedokázali vyřešit bez použití počítačủ a jejich brutální komputační síly, at' už se jedná o topologický problém čtyř barev, nebo modelování sekvencí DNA. Věda je závislá na faktorech nacházejících se vně našich hlav, vědecký vývoj si už nelze představit bez součinnosti s externími objekty a agenty. Vědecký výzkum je rozšířením zdravého rozumu pomocí experimentálních a kvantitativních metod. Quine v návaznosti na Huma a mnohé další myslitele vystihl jeho charakter takto:

Věda sama je pokračováním zdravého rozumu. Vědec se neliší od obyčejného člověka tím, co považuje za evidenci, je jen pečlivější. Tato zvýšená pečlivost nespočívá v revizi zásad dokazování, ale jedná se o trpělivější a systematičtější shromažd’ování a využívání toho, co by kdokoli mohl považovat za důkaz (Quine 1957, 5 - 6; český překlad podle Tvrdý 2018, 58).

Jedním ze současných předpokladů vědy je možnost kontroly pomocí recenzního řízení či replikace výsledků na základě veřejně dostupných datových souborů. Aby mohl být badatel odborníkem v určité oblasti, musí se zaměřit na dosti limitovanou sféru lidského poznání. Tato specializace způsobuje, že principiálním základem vědy je dělba práce, což můžeme opět dohledat ve Smithově díle:

Jak se společnost vyvijí, stává se filosofie nebo myslitelství, jako každé zaměstnání, hlavním nebo jediným oborem a povoláním určité vrstvy občanů. Jako každé jiné zaměstnání, i ona je rozdělena na množství různých oborů, z nichž každý zaměstnává jistou skupinu filosofů. I ve filosofii, stejně jako při každé jiné činnosti, zvyšuje taková dělba práce dovednost a šetři čas. Každý jednotlivec se stává ve svém oboru lepším znalcem, vykoná se dohromady více práce a věda se tím značně obohatí (Smith 2016, 12).5

Nabízí se, abychom tento způsob uspořádání vědeckého provozu označovali termínem dèlba kognitivní práce (division of cognitive labour), který v kontextu filozofie vědy zřejmě poprvé použil Philip Kitcher (1990). Pro účely tohoto článku nejsou

${ }^{5}$ Připomínám, že autor ještě nerozlišuje mezi filozofií a vědou a termíny philosophy, speculation či science používá v textu synonymně. 
ale Kitcherovy úvahy o rozhodování mezi alternativními hypotézami, teoriemi a výzkumnými programy v rámci vědeckého společenství př́iliš podstatné. Mnohem důležitější se mi jeví způsob použití pojmu mezi dnešními vývojovými, kognitivními a sociálními psychology. Ti totiž často mluví o tom, jak hyperspecializace lidské společnosti vede $\mathrm{k}$ fragmentaci znalostí do mnoha myslí, z nichž žádná není schopná pojmout současný stav bádání v celé jeho šíři (např. Lutz, Keil 2002; Keil et al. 2008). Snad nejvhodnější by ale bylo mluvit v tomto kontextu o dèlbě epistemické práce, která se odehrává nad rámec individuální kognice.

Právě neporozumění povaze vědeckého poznání znemožňuje mysteriánům nahlédnout defektnost jejich argumentace. Dennett př́mo mluví o distribuovaném porozuměni (distributed understanding), které je rozprostřeno např̌́c epistemickými agenty ve vědeckém společenství i za jeho hranicemi: ,my jako skupina můžeme rozumět i tomu, čemu nikdo z nás jednotlivě porozumět nedokáže“ $(2017,375)$. I když jsou mysteriáni jako McGinn přesvědčeni, že nechápou problém vědomí a že ho ani nikdy pochopit nesvedou, neznamená to ještě, že věda někdy v budoucnu nezformuluje úplné vysvětlení fenomenálních obsahů, byt' by to přesahovalo intelektuální schopnosti jejích představitelů. Z psychologické uzávěry jednotlivce totiž ještě nevyplývá kognitivní uzávěra celého vědeckého společenství. To je také závěr, ke kterému dospívají belgičtí filozofové vědy Michael Vlerick a Maarten Boudry $(2017,105)$. Existuje podle nich celá řada vědeckých teorií, které vzdorují pokusům o pochopení pomocí zdravého rozumu. U komplikovaných témat, jako je evoluční biologie, kvantová mechanika nebo teorie relativity, může mnohým lidem chybět onen ,aha zážitek“, který si s pochopením spojují. Vlerick a Boudry před takovým intuitivním pojetím porozumění varují: ,je absurdní vyvozovat, že nemůže být vytvořena žádná vědecká teorie o psychofyzickém spojení jen proto, že náš zdravý rozum nedokáže uchopit řešení problému“ $(2017,110)$.

\section{Iluze nevědění}

Psychologové věnují v poslední době značnou pozornost kognitivnímu zkreslení, kterému v důsledku specializace poznání lidé běžně podléhají. Jedná se o tzv. iluzi vědění (knowledge illusion), kdy epistemičtí agenti navenek inzerují pochopení složitých problémů či artefaktů, o nichž ve skutečnosti mají jen velice mlhavou představu (např. Rozenblit, Keil 2002). Pokud jsou probandi vyzváni, aby posoudili a ohodnotili svou znalost fungování šicího stroje, otvíráku na konzervy, vodní elektrárny, autobaterie, zdrhovadla, rychloměru, srdce, vrtulníku, telefonu nebo toalety, vykazují obvykle velkou sebejistotu. Při podrobnějším dotazování ovšem zjišt'ují, že jejich schopnost vysvětlení je značně limitovaná a většinou spočívá $\mathrm{v}$ tezovitých tvrzeních fragmentární povahy, za nimiž se skrývá nepochopení př́slušných kauzálních mechanismů. Iluze 
vědění je způsobena skutečností, že jako členové epistemického společenství nedokážeme přesně odlišit, které poznatky máme $\mathrm{k}$ dispozici my sami a které se nacházejí v myslích jiných osob (Sloman, Fernbach 2017, 127 - 128). Dělba epistemické práce způsobuje, že se velmi často spoléháme na znalosti našeho okolí, i když je sami neovládáme.

Domnívám se, že takto můžeme vysvětlit i předpoklady mysteriánského uvažování. Nesprávně chápaná dělba epistemické práce je dvojsečnou zbraní, protože může neinformované jedince vést $\mathrm{k}$ iluzi vědění i iluzi nevědění. Stejně jako mohou mít lidé intuitivní a nezdůvodněný pocit, že něčemu rozumí, mohou se stejně nezdůvodněně domnívat, že je jim určité poznání upřeno. Je dost dobře možné individuálně pocitovat, že nemáme ponětí o fungování vědomí nebo svobodné vůle, i když jsou tyto informace už př́ítomné v celku vědeckého společenství. Analogicky skutečnost, že já jako jednotlivec nejsem schopen pochopit a vysvětlit činnost spalovacího motoru, neznamená, že je tento stroj záhadou, nevysvětlitelným tajemstvím. Lidské ruce ho vytvořily, lidské mozky mu rozumějí. A podobně je to podle mého názoru s jinými záhadami mysteriánů. Nemám sice jednoduchý recept na jejich řešení, ale mohu nabídnout obecnější epistemologickou maximu. Musíme být ve svých úsudcích realističtí a vyvarovat se iluzi vědění. Zároveň ale nesmíme podléhat mysteriánskému poraženectví a utápět se v iluzi nevědění. Je třeba mít se na pozoru a s nejvyšší obezřetností navigovat mezi Skyllou epistemické arogance a Charybdou př́lišné bojácnosti.

\section{Literatúra}

BOIS-REYMOND, E. du (1874): The Limits of Our Knowledge of Nature. The Popular Science Monthly, 5, 17 - 32.

BOIS-REYMOND, E. du (1882): The Seven World Problems. The Popular Science Monthly, 20, $433-447$.

CLARK, A., CHALMERS, D. (1998): The Extended Mind. Analysis, 58 (1), 7 - 19. DOI: https:// doi.org/10.1093/analys/58.1.7

COLLINS, J. (2002): On the Very Idea of a Science Forming Faculty. Dialectica, 56 (2), 125 - 151. DOI: https://doi.org/10.1111/j.1746-8361.2002.tb00235.x

COMTE, A. (1853): The Positive Philosophy, Vol. 1. Přel. Harriet Martineau. London: John Chapman.

DARWIN, Ch. (1871): The Descent of Man. D. Appleton and Co.

DARWIN, Ch. (2006): O pưvodu člověka. Přel. Josef Wolf a Zora Wolfová. Praha: Academia.

DENNETT, D. C. (1991): The Brain and Its Boundaries: Review of The Problem of Consciousness, by Colin McGinn. The Times Literary Supplement, 10. květen 1991.

DENNETT, D. C. (2017): From Bacteria to Bach and Back: The Evolution of Minds. New York: W. W. Norton \& Company.

FLANAGAN, O. J. (1991): The Science of the Mind. 2. vyd. Cambridge: MIT Press.

FODOR, J. A. (1983): The Modularity of Mind: An Essay on Faculty Psychology. Cambridge: MIT Press. 
HEARNSHAW, J. (2010): Auguste Comte's Blunder: An Account of the First Century of Stellar Spectroscopy and How It Took One Hundred Years to Prove That Comte Was Wrong! Journal of Astronomical History and Heritage, 13 (2), 90 - 104.

HORGAN, J. (2015): The End of Science: Facing the Limits of Knowledge in the Twilight of the Scientific Age. New York: Basic Books.

HŘÍBEK, T. (2017): Jaké to je, nebo o čem to je? Misto vědomí v materiálním světě. Praha: Filosofia.

HUME, D. (2007): A Treatise of Human Nature: A Critical Edition. Oxford: Clarendon Press.

HUXLEY, T. H. (1866): Lessons in Elementary Physiology. London: Macmillan.

HUXLEY, T. H. (1872): Lessons in Elementary Physiology. 6. vyd. London: Macmillan.

CHOMSKY, N. (1975): Problems and Mysteries in the Study of Human Language. In: Reflections on Language. New York: Pantheon Books, 137 - 227.

CHOMSKY, N. (1976): Problems and Mysteries in the Study of Human Language. In: Asa Kasher (ed.): Language in Focus: Foundations, Methods and Systems - Essays in Memory of Yehoshua Bar-Hillel. Dordrecht: D. Reidel Publishing Company, $281-357$.

CHOMSKY, N. (1988): Language and Problems of Knowledge: The Managua Lectures. Cambridge: MIT Press.

CHOMSKY, N. (1991): Linguistics and Cognitive Science: Problems and Mysteries. In: Kasher, A. (ed.): The Chomskyan Turn. Oxford: Blackwell, 26-53.

CHOMSKY, N. (1993): Language and Thought. Wakefield: Moyer Bell.

CHOMSKY, N. (1994): Naturalism and Dualism in the Study of Language and Mind. International Journal of Philosophical Studies, 2 (2), 181 - 209. DOI: https://doi.org/10.1080/09672559408570790

CHOMSKY, N.(1995): Language and Nature. Mind, 104(413), 1-61.DOI: https://doi.org/10.1093/mind/104.413.1

CHOMSKY, N. (2000): Language as a Natural Object. In: New Horizons in the Study of Language and Mind. Cambridge: Cambridge University Press, 106 - 133.

CHOMSKY, N. (2009): The Mysteries of Nature: How Deeply Hidden? The Journal of Philosophy, 106 (4), 167 - 200. DOI: https://doi.org/10.5840/jphil2009106416

INWAGEN, P. van (1998): The Mystery of Metaphysical Freedom. In: Peter van Inwagen - Dean W. Zimmerman (eds.): Metaphysics: The Big Questions. Oxford: Blackwell, 365 - 374.

INWAGEN, P. van 2000: Free Will Remains a Mystery. Noûs, 34 (14), 1 - 19. DOI: https://doi.org/10.1111/0029-4624.34.s14.1

KANT, I. 1975. Kritika soudnosti. Přel. Vladimír Špalek a Walter Hansel. Praha: Odeon.

KEIL, F. C., STEIN, C., WEBB, L., BILLINGS, V. D., ROZENBLIT, L. (2008): Discerning the Division of Cognitive Labor: An Emerging Understanding of How Knowledge Is Clustered in Other Minds. Cognitive Science, 32 (2), 259 - 300. DOI: https://doi.org/10.1080/03640210701863339

KIRCHHOFF, G., BUNSEN, R. (1860): Chemische Analyse durch Spectralbeobachtungen. Annalen der Physik, 186 (6), $161-189$.

KITCHER, P. (1990): The Division of Cognitive Labor. The Journal of Philosophy, 87 (1), 5 - 22. DOI: https://doi.org/10.2307/2026796

LEVINE, J. (1983): Materialism and Qualia: The Explanatory Gap. Pacific Philosophical Quarterly, 64 (3), 354 - 364. DOI: https://doi.org/10.1111/j.1468-0114.1983.tb00207.x

LUTZ, D. J., KEIL, F. C. (2002): Early Understanding of the Division of Cognitive Labor. Child Development, 73 (4), 1073 - 1084. DOI: https://doi.org/10.1111/1467-8624.00458

McGINN, C. (1989): Can We Solve the Mind-Body Problem? Mind, 98 (391), 349 - 366. DOI: https://doi.org/10.1093/mind/XCVIII.391.349

McGINN, C. (1991): The Problem of Consciousness: Essays Towards a Resolution. Oxford: Blackwell.

McGINN, C. (1993): Problems in Philosophy: The Limits of Inquiry. Oxford: Blackwell. 
NAGEL, T. (1974): What Is It Like to Be a Bat? The Philosophical Review, 83 (4), 435 - 450. DOI: https://doi.org/10.2307/2183914

NAGEL, T. (1986): The View from Nowhere. Oxford: Oxford University Press.

PENROSE, R. (2004): The Road to Reality: A Complete Guide to the Laws of the Universe. London: Jonathan Cape.

PINKER, S. (1997): How the Mind Works. New York: Norton.

PUTNAM, H. (1973): Meaning and Reference. The Journal of Philosophy, 70 (19), 699 - 711. DOI: https://doi.org/10.2307/2025079

QUINE, W. V. O. (1957): The Scope and Language of Science. The British Journal for the Philosophy of Science, 8 (29), 1 - 17. DOI: https://doi.org/10.1093/bjps/VIII.29.1

ROZENBLIT, L., KEIL, F. C. (2002): The Misunderstood Limits of Folk Science: An Illusion of Explanatory Depth. Cognitive Science, 26 (5), 521 - 562. DOI: https://doi.org/10.1207/s15516709cog2605_1

SLOMAN, S. A., FERNBACH, P. (2017): The Knowledge Illusion: Why We Never Think Alone. New York: Riverhead Books.

SMITH, A. (2016): Pojednání o podstatě a pưvodu bohatství národů. Přel. Vladimír Irgl, Alena Jindrová, Josef Pytelka a Sergej Tryml. Praha: Liberální institut.

TVRDÝ, F. (2014): Turingův test: filozofické aspekty umělé inteligence. Praha: Togga.

TVRDÝ, F. (2015): Nesnáze introspekce: svoboda rozhodování a morální jednání z pohledu filozofie a védy. Praha: Togga.

TVRDÝ, F. (2018): Antiscientismus, konceptuální analýza, naturalismus. Pro-Fil, 19 (1), 49 - 61. DOI: https://doi.org/10.5817/pf18-1-1764

TYNDALL, J. (1879): Scientific Materialism. In: Fragments of Science, Vol. 2, 6. vyd., 75 - 90. London: Longmans, Green, and Co.

VLERICK, M., BOUDRY, M. (2017): Psychological Closure Does Not Entail Cognitive Closure. Dialectica, 71 (1), 101 - 115. DOI: https://doi.org/10.1111/1746-8361.12176

Zpracování publikace bylo umožněno díky finanční podpoře Filozofické fakulty Univerzity Palackého v Olomouci v letech 2019 - 2022 z Fondu pro podporu vědecké činnosti.

Filip Tvrdý

Univerzita Palackého v Olomouci

Filozofická fakulta, Katedra filozofie

Křížkovského 12

77900 Olomouc

Česká republika

e-mail: filip.tvrdy@upol.cz

ORCID ID: https://orcid.org/0000-0003-1264-9854 